\title{
DESEJO E NEGAC̄̃̃ - A FALTA SITUADA NO CORAÇÃO DO SER (UMA HOMENAGEM A BARBARAS)
}

\author{
Desire and negation - lack in situated in the heart of being (a tribute to Barbaras) \\ Deseo y negación - la falta situada en el corazón del ser (un homenaje a Barbaras)
}

Resumo: Propomos, no texto que se segue, retomar a fina e acurada leitura realizada por Barbaras em torno da problemátiça sartriana do desejo e sua relação com a negação. Trata-se de pensar o fenômeno da falta situada no coração do ser. É, portanto, no contexto desse tema que nasce a questão posta por Barbaras: "Como pode haver desejo, se o desejado não pode ser de alguma maneira?". Busca-se mostrar que, para além de certo realismo ingênuo de Sartre, há uma enorme diferença entre a ontologia fenomenológica não idealista e a ingenuidade realista pela qual insiste-se em ler a ontologia sartriana. Assim, ao invés da identificação entre desejo e falta (o que, irremediavelmente, indica certo grau de vontade), a ontologia de Sartre é - sem mais - ontologia da negatividade: Ser e Nada referem-se ao ser categorial (ontológicos), enquanto ser-para-si e ser-em-si são existentes (ônticos, fenômenos enfim); numa palavra, Sartre perverte intencionalmente o método puritanamente fenomenológico.

Palavras-chave: Renaud Barbaras; Desejo; Negação; Falta; Sartre.

\begin{abstract}
The purpose of this paper is to reflect about Barbaras' lecture of the Sartrian desire problem and its relation to negation. This question is situated inside the phenomenon of lack in the heart of being. It is, therefore, in the context of this theme that the question posed by Barbaras arises: "How can exists desire, if the desired cannot be in any way?" The point is demonstrating that, beyond Sartre's naïve realism, there is a huge difference between the non-idealist phenomenological ontology and the naïve realistic by which ones insists on reading the Sartrian ontology. Thus, instead of the identification desire and lack (which inevitably indicates a certain degree of will), Sartre's ontology is - in fact - ontology of negativity: Being and Nothing refer to being categorial (ontological), but being-to-itself and being-in-themselves are existential (ontically - they are both phenomena); in this way, Sartre deliberately changes the purity phenomenological method.
\end{abstract}

Keywords: Renaud Barbaras; Desire; Negation; Lack; Sartre.

Resumen: En el texto siguiente, proponemos retomar la fina y exacta lectura realizada por Barbaras a respecto de la problemática sartriana del deseo y su relación con la negación. Busca-se pensar el fenómeno de la falta situada en el corazón del ser. Es, por lo tanto, en el contexto de ese tema que nace la cuestión planteada por Barbaras: “¿Cómo puede haber deseo, si lo deseado no puede ser de alguna manera?”. Intenta-se mostrar que, además de cierto realismo ingenuo de Sartre, hay una diferencia entre una ontología fenomenológica no idealista y la ingenuidad realista por la que se insiste en leer la ontología sartriana. Por lo tanto, en lugar de la identificación entre deseo y falta (lo que, sin remedio, indica cierto grado de voluntad), la ontología de Sartre es - sin embargo - ontología de la negatividad: Ser y Nada se refieren al ser categorial (ontológicos), mientras el ser-para-si y ser-en-sí son existentes (ónticos, fenómenos al cabo); en una palabra, Sartre no sigue el método puritanamente fenomenológico.

Palabras clave: Renaud Barbaras; Deseo; Negación; Falta; Sartre.

...pois o mesmo é a pensar e a ser. Parmênides ${ }^{1}$

O homem é fundamentalmente desejo de ser e a existência desse desejo não deve ser estabelecida por uma indução empírica; mas resulta de uma descrição a priori do ser do Para-si, posto que o desejo é falta, e o Para-si é o ser que é, a si mesmo, sua própria falta de ser. O projeto original que se exprime em cada uma de nossas tendências empiricamente observáveis é, assim, o projeto de ser.

(Sartre, 2011, p. 692)

\section{Introdução}

O existencialismo sartriano, ou mais propriamente sua filosofia da liberdade, parece ser o alvo preferido tanto de marxistas de todas as cas-

1 Parmênides. Poema. Fragmento 3. Trad. Fernando Santoro. Disp. https://pt-static.z-dn.net/.../ad427688417a96 f5e31d7c7d8aa8336a, consulta 30-08-2017, 11h11. tas quanto de liberais de todos os níveis. Nos anos 1960, Sartre foi estudado pela CIA e observado pela KGB: ocorre que suas incursões no plano político desagradaram a "gregos e a troianos", e é daí que advém sua caricatura de um burguês arrependido ou de um traître ou, mesmo, collaborateur. As polêmicas, várias e variadas, cultivadas e documentadas pelo casal Sartre-Beauvoir parecem - ainda hoje, e também na Academia - ter mais importância que sua filosofia. Felizmente, na contramão do modelo vida dos famosos (que abarca boa parte das críticas a Sartre), nosso homenageado volta-se para à filosofia de Sartre: em Désir et manque dans L'Être et le Néant: le désir manqué (2005), o professor Renaud Barbaras dirige-se a Sartre como filósofo. E, de filósofo para filósofo, pergunta:

Não é porque Sartre não efetua a épokhé fenomenológica e permanece prisioneiro de um pressuposto ingenuamente realista que ele lê a ausência do objeto em esboço como um puro 
não-ser, mais que como um modo de ser, um estilo singular de presença? (Barbaras, 2005, p. 140).

\section{E responde:}

$\mathrm{Na}$ verdade, tudo se passa como se Sartre não pudesse voltar ao final senão nisso que ele colocou implicitamente no início, a saber, um ser-em-si, em nome do qual toda forma de manifestação envolvendo a distância ou ausência será finalmente concebida como não-ser (Barbaras, 2005, p. 140).

Desse modo, não se trata de mostrar que as diferenças de Sartre com marxistas tanto podem ser creditadas à exigência de liberdade do filósofo quanto à necessidade autoritária do marxismo; nem de relevar razões pelas quais as razões de Sartre deveriam também ser ouvidas, apesar das queixas de Camus ou Merleau-Ponty ou qualquer outro. Barbaras homenageia Sartre quando, ao invés de prender-se a detalhes bio-bibliográficos, promove o debate filosófico; e, ainda que sua conclusão revele - da perspectiva da fenomenologia husserliana os limites da fenomenologia de Sartre, a seriedade com que Barbaras encara os meandros de L'Être et le Néant (O Ser e o Nada, ora em diante EN), expressa verdadeiramente um diálogo de filósofos. E, como tal, merece nossa atenção.

À César o que é de César: os filósofos que se entendam. Assim, a pretensão desse artigo é bem mais modesta do que a homenagem prestada por Barbaras a Sartre. Ora, não se trata de discutir as razões pelas quais torna-se relevante - no interesse da filosofia barbarariana, por assim dizer - revelar de modo analítico a aporia maior de EN. Pois, vista de sua conclusão, a crítica de Barbaras até parece repetir aquela quase revelação merleau-pontyana, de que a filosofia de Sartre é mero sobrevoo; mas não. A sutileza e profundidade da argumentação tecida em Desejo e falta é, ainda que homenagem, uma das mais devastadoras críticas contemporâneas endereçadas à ontologia fenomenológica de Sartre. Ela abarca a estrutura mesma do pensamento sartriano, e o ensaio de ontologia fenomenológica permanece reduzido à uma hipérbole do em-si: parte-se do ser-em-si e retorna-se ao ser-em-si, ou nem mesmo isso? Em $O$ Visível e o Invisível, Merleau-Ponty - num sentido próximo e distante de Barbaras - resume a descrição do ser-para-si sartriano como autonegação do nada. Assim, perto de Merleau-Ponty, na medida em que uma filosofia do negativo "descreve nossa situação de fato com uma acuidade jamais levada a cabo - e, no entanto, fica a impressão de que nossa situação foi 'sobrevoada' e o é de fato" (Merleau-Ponty, 2005, p. 89) - Barbaras decide pelo engodo do projeto sartriano de tentar "determinar o sentido da consciência e o sentido do ser, de tal maneira que seja pensável a intencionalidade como 'intuição revelante” (Barbaras, 2005, p. 114). E as razões aventadas por Barbaras o colocam bem longe do pensamento merleau-pontyano, para quem a ontologia de Sartre e nega-intuição do nada que revela sua distinção absoluta, ao passo que, para Barbaras, Sartre jamais foi além do ser-em-si. ${ }^{2}$ À parte, Merleau-Ponty e suas considerações, o fato é que nem mesmo a respeito das razões do engodo da fenomenologia sartriana há acordo; parece mais acertado dizer que, do ponto de vista de uma fenomenologia da percepção, à fenomenologia da consciência intencional situada teria faltado carne (ou o corpo, ou corporeidade, ou natureza - razões das diferenças entre Sartre e Merleau-Ponty). No mesmo sentido, aos olhos da fenomenologia mesma (da qual Barbaras é tributário), a ontologia fenomenológica de Sartre - porque recusa-se a efetuar a épokhé fenomenológica - oscilaria entre realismo ingênuo ou megalomania.

\section{Sartre, Barbaras e a ontologia do ser mundano- situado}

Todavia, onde encontrar o parâmetro para decidir qual dos projetos filosóficos que se autodenominam fenomenológicos é, de fato, a fenomenologia? Ela foi aventada primeiro por Husserl, é certo, mas ainda em presença do pai da fenomenologia, Heidegger escreveu sua ontologia fenomenológica do Dasein Humano - algo que, aos olhos do mestre, revelou toda a carga antropológica que então determinava a mais nova geração de filósofos alemães (1930) (Husserl, 1994, p. 57ss). A filosofia de Sartre apresenta matizes dessa virada: EN nasce não somente do projeto fenomenológico husserliano, mas também da assertiva de Heidegger, de que Husserl, com a noção de intuição categorial, libertou o ser do juízo. A questão epistemológica tende a esconder o fato de que, além de Sartre e mesmo na França, bem que se poderia falar de uma quarta noção da fenomenologia, aquela de Merleau-Ponty. O que elas têm em comum? O que as difere? Não é hora para taxonomia, pois nesse ponto Barbaras facilita o trabalho:

A épokhé designa precisamente o acesso à correlação sob sua face [versant] objetiva: ela coloca entre parênteses a existência em-si, isto é, não relativa, do transcendente para fazer aparecer sua pertença à fenomenalidade. [...] em O Ser e o Nada. Essa obra aparece precisamente como uma tentativa de determinar o sentido da consciência e aquele do ser, de tal

\footnotetext{
2 Merleau-Ponty critica a ontologia de EN porque Sartre não teria conferido o justo estatuto do mundo fenomênico, enquanto mistura entre $o$ ser e o nada; ou seja, "Meu ponto de partida está onde Sartre tem seu ponto de chegada: no Ser retomado pelo Para si - Este é seu ponto de chegada porque ele parte do ser e da negatividade e constrói sua união. Para mim é a estrutura ou a transcendência quem explica, uma vez que o ser e o nada (no sentido de Sartre) são duas propriedades abstratas" (Merleau-Ponty, 2005, p. 290). Ainda, "A partir do momento em que me concebo como negatividade e o mundo como positividade, não há mais interação. Caminho eu próprio diante de um mundo maciço; entre ele e mim não há encontro nem fricção, porquanto ele é o Ser e eu nada sou. Somos e permanecemos estritamente opostos e confundidos, precisamente porque não somos da mesma ordem. Permaneço no centro de mim mesmo absolutamente estranho ao ser das coisas - e justamente por isso destinado a elas, feito para elas. (Merleau-Ponty, 2005 , p. 78). Por fim, conclui Merleau-Ponty (2005, p. 99), "Sartre diz bem que no fim de seu livro será permitido passar a um sentido mais amplo do Ser, que contenha o Ser e o nada. Isso, porém, não quer dizer que a oposição inicial tenha sido ultrapassada".
} 
maneira que seja pensável a intencionalidade como uma "intuição revelante" (Barbaras, 2005, p. 113-114).

A descrição do projeto de Sartre não poderia ser mais precisa: de fato, para ele, há presença da consciência ao ser, e sua ontologia fenomenológica pretende descrever justamente essa presença (ser-para-si) em presença social (ser-para-outro). Todavia, não se trata de pensar a intuição como mera revelação, pois a par da presença da consciência ao ser, a filosofia de Sartre exige que também o ser esteja presente à consciência. Assim,

[...] o conhecimento não pode por si fornecer a razão do ser, ou melhor, que o ser do fenômeno não pode se reduzir ao fenômeno do ser. Em resumo, o fenômeno de ser é "ontológico", no sentido em que chamamos de ontológica a prova de Santo Anselmo e Descartes. É um apelo ao ser; exige, enquanto fenômeno, um fundamento que seja transfenomenal (Sartre, 2011, p. 20).

Ora, aqui cabe ao menos retomar o caminho percorrido por Barbaras em EN e, a partir dele - se possível - colocar em relevo aspectos que possam abrandar sua conclusão, de que o existencialismo e todas as consequências da filosofia da liberdade tenham nascido de um pressuposto ingenuamente realista.

A primeira aproximação de Sartre da fenomenologia, seja no anedótico episódio com Aron ( $\mathrm{CO}$ quetel de abricó), seja na retrospectiva discussão metodológica (Questão de Método), não deixa margem para dúvida: "queríamos partir do concreto total e chegar ao concreto absoluto" (Sartre, 2002, p. 29). A concretude almejada por Sartre, porém, nada tem que ver com alguma sorte de realismo epistemológico. Para o filósofo, “o concreto só pode ser a totalidade sintética da qual tanto a consciência como o fenômeno são apenas momentos" (Sartre, 2011, p. 43). É nesse contexto que se pode falar da consciência como aquela que revela o sentido do ser; mas é também assim que se pode falar que exista consciência: o ser-para-si é em-si que se faz si (para-si). Quando visado pela consciência, trata-se do ato de escolher ser (escolha original) e fazer-se no mundo; quando mirado - também pela consciência, evidentemente - a partir de seu outro (Ser), o sacrifício do Ser em ser-para-si vai se resumir ao misterioso e impenetrável enigma do acontecimento original - uma existência que se revela como sendo seu passado e, claro, seu futuro. Isso permite entrever outro caminho na ontologia fenomenológica de Sartre que, ainda que passe perto da crítica proposta por Barbaras, não permite chegar às mesmas conclusões que ele; ou seja, o fracasso da empreitada de Sartre - reiterado entre tantos de seus leitores - parece repetir um vício de princípio: partir do Cogito. Mas, cabe lembrar, isso não encerrou a filosofia da liberdade no solipsismo; e, ainda que toda metafísica tenha sua teoria do conhecimento (e vice-versa), a ontologia fenomenológica de Sartre coloca-se entre a metafísica e as exigências epistemológicas: é uma ontologia fenomenológica. Assim, parece um tanto forte partir da ideia de que, porque Sartre caracteriza o desejo como falta, ele retira o em-si de sua fenomenalidade e postula a independência do em-si em relação à fenomenalidade - sendo a solução do enigma dada de barato: Sartre não efetuou a redução fenomenológica. Pode ser que a vontade realista de Sartre tenha sim o levado à Alemanha para estudar a fenomenologia, mas é essa mesma vontade a responsável por ele - considerando-se fenomenólogo (sua ontologia é fenomenológica) - manter a noção de intencionalidade da consciência e, recusando-se a efetuar qualquer nível da épokhé, colocar em seu lugar uma variante ampliada da noção heideggeriana da situação. E, assim, a fenomenologia de Sartre, em seu início, comporta elementos tanto do método transcendental de Husserl quanto da analítica do Dasein mundano concreto de Heidegger; e, por certo, os rumos que ela toma também tem seu alter ego no debate com Merleau-Ponty, e sua fenomenologia da percepção.

Dito isso, cabe uma reparação na tese proposta por Barbaras: a ingenuidade de Sartre fica evidente ao final de seu trabalho, e pode ser mantida com a ressalva de que é assim para certa noção da fenomenologia; e que seja a primeira, ou aquela que é fiel a Husserl ou seja o que for, não muda o fato de que se trata de uma fenomenologia - jamais $d a$ fenomenologia. A vontade de verdade - denunciada por Nietzsche - renasce de modo contundente no projeto fenomenológico de Husserl: o idealismo transcendental beira sim a megalomania, ao propor que “'Fenomenologia' - designa uma ciência, uma conexão de disciplinas científicas; mas, ao mesmo tempo e acima de tudo, 'fenomenologia' designa um método e uma atitude intelectual: a atitude intelectual especificamente filosófica, o método especificamente filosófico" (Husserl, 1990, p. 46). Somente ao filósofo pode caber tão grandiosa tarefa, mas qual filósofo? Descrever o a priori da correlação a partir do campo transcendental absolutamente purificado? Aquele do Ego Cogito como subjetividade transcendental? Pode ser, mas para isso será preciso, primeiro, admitir que "este mundo é para nós apenas um simples fenômeno elevando uma pretensão de existência” (Husserl, 2013, p. 56); e, pior, "isto diz também respeito à existência intramundana de todos os outros eus, de tal modo que não deveríamos mais falar propriamente no plural comunicativo" (Husserl, 2013, p. 56). Sartre, considerando-se que queria partir do concreto total, jamais poderia admitir a primeira assertiva; ainda menos a segunda, se de fato pretende chegar ao concreto absoluto, ou, mesmo, falar em liberdade. Não é por acaso que todas as investidas da filosofia de Sartre, ao menos até os primeiros contatos com a doutrina de Heidegger, são de crítica a Husserl, ou de busca de alternativa à sua proposta de colocar o estar-aí-adiante das coisas entre parênteses: não permanecer no plano da atitude natural e, ainda assim, partir do concreto, é a incógnita fenomenológica revelada pela introdução de EN. Mas não é tudo.

Notável que seja preciso perder para ganhar, 
mas a Sartre não pareceu um bom negócio trocar toda a riqueza dos fenômenos mundano-concretos, ainda que em sua nebulosidade, pela clareza - que fosse maior que do sol - das verdades a priori. Nunca faltou a épokhé na filosofia da liberdade: ela foi rejeitada porque encaminha, sem volta, ao transcendental e seu necessário idealismo. A promessa feita ao filósofo por Aron não pode se cumprir nos termos em que o próprio Husserl escreveu seu projeto fenomenológico; as obras que antecedem (e preparam) EN testemunham isso. (Cf. Sartre, 1938, 1973, 1994, 1996). Mas o que se pode dizer caso se leve a sério a proposta de Sartre, de uma liberdade situada? O que EN teria a ensinar sobre a também hiperbólica ilusão sartriana, de pensar escrever um livro sobre nada enquanto, na verdade - conforme a tese de Barbaras - ele jamais abandonou a nega-intuição do ser-em-si? Em suas palavras, Sartre, ao caracterizar o desejo como falta, não pode entrever a correlação senão em ato, donde "esse fracasso se enraíza em um pressuposto ontológico fundamentalmente realista, isto é, fenomenologicamente ingênuo, que conduz a introduzir uma dissimetria entre o para-si e o em-si” (Barbaras, 2005, p. 115). Mas a própria escolha do termo, dissimetria, não revela uma decisão teórica prévia - de Barbaras, evidentemente - pelo idealismo e sua simétrica totalidade? Ou, melhor dito, de fato Sartre mantém entre em-si e para-si uma relação que - afirmada entre o em-si e o para-si - não pode ser re-afirmada quando vista do em-si ao para-si. Sartre (2011, p. 39) é direto:

O ser-Em-si não possui um dentro que se oponha a um fora e seja análogo a um juízo, uma lei, uma consciência de si. O Em-si não tem segredo: é maciço. Em certo sentido, podemos designá-lo como síntese. Mas a mais indissolúvel de todas: síntese de si consigo mesmo. Resulta, evidentemente, que o ser está isolado em seu ser e não mantém relação alguma com o que não é.

Mas a continuidade da leitura parece indicar ao menos um aspecto desse modelo sartriano que Barbaras não considera: o ser-em-si não mantém relação com o que não é. Ora, daí parece lícito concordar com Barbaras, quando ele coloca em evidência a positividade, incomensurabilidade e totalidade do Ser. Todavia, em EN encontram-se ao menos duas noções de ser: a totalidade de tudo que é (Ser) enquanto relação entre ser-em-si e ser-para-si. Caso Ser e Nada sejam considerados de seu ponto de vista absoluto, tanto a crítica de Merleau-Ponty quanto essa de Barbaras se justificam; mas e se aquela distinção proposta por Sartre - entre metafísica e ontologia - for considerada, essa impressão permaneceria? $\mathrm{Ou}$, ainda, caso se coloque em foco não a falta de ser como desejo, mas estritamente como propõe Sartre - como falta de ser que se faz projeto de ser $^{3}-$

\footnotetext{
3 Interessante notar que há sim similitude entre o modelo de falta ontológica e o fundamento do desejo, ou, entre Sartre e Lacan. Todavia, essa proximidade precisa ser mediada: Lacan combateu ferrenhamente a redução organicista da subjetividade, e seu caminho - de acordo com Vladimir Safatle - leva às dinâmicas de socialização do desejo. Assim, "a racionalidade de sua clínica pode assim depender de problemas ligados ao reconhecimen-
}

daria para manter a afirmação de que a filosofia de Sartre se resume à autonegação do negativo, como pretendeu Merleau-Ponty? Ou, o que daria no mesmo, como afirmação da afirmação, como mostra Barbaras no tocante ao Ser?

O projeto fenomenológico da maneira como foi proposto por Husserl não deixa outra opção senão a admissão de que o fenômeno - porque camada constituinte - é distinto do Ser; o idealismo é a panaceia. Que seja. A descrição do a-priori da correlação deverá justamente explicar essa relação, e Sartre fala de um movimento negativo do ser-para-si em relação ao ser-em-si, não uma relação entre Ser e Nada; nada de estranho que a negação de uma negação produza uma afirmação, mas, por que limitar esse instrumento ao plano do mero conhecimento? Ora, se a ontologia é fenomenológica, Sartre fala de fenômenos: ser-para-si é um fenômeno que é negação de ser. Isso leva, de imediato, à tese aqui debatida, qual seja, Sartre não admite o idealismo, isso é certo; mas há uma diferença enorme entre uma ontologia fenomenológica não idealista e a ingenuidade realista pela qual insiste-se em ler sua ontologia. Culpa em parte de Sartre mesmo, que embora mantenha em sua obra o constante diálogo entre os âmbitos ôntico e ontológico, não toma o cuidado de informar sobre suas errâncias e limites; mas a negação situada, esse recurso existencial desenvolvido por Sartre a partir de Heidegger, não permite reduzir o Ser a um isto, ainda que seu uso (Ser e ser-em-si) seja, em EN, indiscriminado. Assim, ao invés da identificação entre desejo e falta (o que, irremediavelmente, indica certo grau de vontade), a ontologia de Sartre é - sem mais - ontologia da negatividade: Ser e Nada referem-se ao ser categorial, ser-para-si e ser-em-si são existentes - fenômenos enfim -, mas não no sentido puritanamente fenomenológico. Em consonância com Heidegger, também para Sartre

Aquilo, entretanto, que segundo sua essência, antecipa projetando algo tal como em-vista-de em geral e não o produz também como eventual resultado de um esforço, é o que chamamos liberdade. A ultrapassagem para o mundo é a própria liberdade. Por conseguinte, a transcendência não se depara com o em-vista-de como um valor ou um fim por si existente; mas liberdade - é, na verdade, como liberdade - mantém o em-vista-de em face de si (Heidegger, 1973, p. 317).

to social de um desejo pensado a partir da noção de negatividade, de uma pulsão cuja verdade é ser pulsão de morte" (Safatle, 2009, p. 79), o que faz sua proposta muito mais próxima de Heidegger que de Sartre. Ademais, ser-para-si é ser falta 'de si' (ser-em-si-para-si, ou ser Deus), e não de alguma sorte de 'coisa': a consciência intencional, mostra o filósofo, é movimento negativo e, enquanto tal, não poderia jamais identificar-se ao 'desejo', ao menos se, conforme atesta Denise Maurano (2006, p. 49), ele - "enquanto conceito psicanalítico" - é "nostalgia da suposta presença da 'Coisa' que teria nos salvado do desamparo. [...]. Tem-se com isso uma passagem do campo da necessidade ao campo do desejo". Sartrianamente falando, falta sim algo ao para-si, mas coisa alguma (ou pessoa, ou ideia, ou seja o que for) poderá preencher essa falta; o deus faltado jamais se realiza, e de princípio a história de cada existência será a história de um fracasso - mas aquilo que fracassa será, invariavelmente, o livre projeto individual de ser. E nem mesmo a morte poderá mudar esse fato; diferente de Lacan, serão a escolha original de ser (projeto) e a ética do porvir os norteadores da psicanálise existencial sartriana. 
Liberdade, nesse caso, é o liame entre em-si e para-si, desde que liberdade situada (ainda que negativa); a negação será o cimento que estrutura o real: trata-se declaradamente de revelação de ser e não mera constituição fenomênica (cognitiva). É fundamental, quando se compara Sartre a Husserl, não esquecer Heidegger; mas também não é aconselhável demorar-se muito aí, pois ainda que a noção de situação heideggeriana tenha sido o ponto de partida de Sartre, vale lembrar que, para ele, trata-se de consciência situada, livre e que se projeta infinita (jamais para-a-morte). Sartre parte do cogito, não se nega; mas com a estrita condição de poder deixá-lo. Torna-se urgente, ainda que isso dê razão a Barbaras no tocante à distância da indagação sartriana e aquela de Husserl, relevar a crítica de Sartre à fenomenologia idealista sob o prisma do conhecimento do ser; enfim, trata-se de mudar o foco, e ver em EN aquilo que ele é: um ensaio de ontologia fenomenológica, e não a constituição de alguma sorte de epistemologia - ainda que fenomenológica.

Não constituir uma epistemologia não exime o filósofo francês de partir de uma: Sartre é fenomenólogo. ${ }^{4}$ E se a Heidegger coube falar do Dasein humano, assim como a Merleau-Ponty falar da percepção (o que justifica falar de analítica existencial fenomenológica ou de fenomenologia da percepção), Sartre desenvolve sua ontologia da consciência situada: "Basta abrir os olhos e interrogar com toda ingenuidade a totalidade homem-no-mundo. Descrevendo-a, podemos responder a estas duas perguntas: $1^{\circ}$ ) Qual é a relação sintética que chamamos de ser-no-mundo? $2^{\circ}$ ) Que devem ser o homem e o mundo para que seja possível a relação entre eles?” (Sartre, 2011, p. 43). E, ao partir do $\mathrm{Co}$ gito e deixá-lo, Sartre estaria meramente assumindo aquilo que o mundo ingenuamente tomado revela? Aquilo que o filósofo explora na introdução de sua ontologia, ou seja, as aporias reveladas pela questão ontológica quando avaliada do ponto de vista do conhecimento (transcendental, a priori, etc.), pode sim ser considerado dessa forma. Mas, logo na primeira parte do livro, o que se tem é a incursão de Sartre por esse mundo - fenomênico, porém não reduzido - e é desse mundo que sua estrutura ontológica é constituída; o ver fenomenológico revela $a$ todo aquele que olhar que o mundo tem ao menos dois tipos de ser: um, que coincide consigo (em-si), e outro, que jamais coincide consigo (para-si). O método progressivo-regressivo, revelado em detalhes na década de 1960, mas já presente em 1943, permite tanto trafegar do particular (o homem que 4 A existência humana é negação de ser, tanto do em-si (pelo qual o homem faz o mundo) quanto de si mesma (para-si); é assim que o ser é trazido ao mundo, no mesmo sentido que Heidegger: "O ente pode vir a ser determinado em seu ser sem que, para isto, seja necessário já dispor de um conceito explícito sobre o sentido do ser" (Heidegger, 2005, p. 33). Mesmo, para Heidegger, o ente homem será, sempre, o responsável pelo sentido do ser graças à primazia de sua abertura a ele: a primazia ôntica e ontológica. $\mathrm{O}$ Dasein é o único ente que, sendo, tem seu ser em jogo. O homem sartriano (ser para-si) funda-se no mesmo solo, mas o faz a partir do homem-consciente (escolha); e, mais, a filosofia da liberdade pode, assim, identificar o ser-no-mundo-consciente (absoluta contingência) como única fonte possível do valor e, consequentemente, de toda ética (prescindindo, portanto, do ser-para-a-morte). eu sou) ao universal (todo homem é para-si), quanto manter uma relação promíscua entre os âmbitos ôntico e ontológico. Isso será mostrado em dois momentos: uma vez colocado em evidência que Sartre não segue a via do conhecimento, mas do ser, será possível averiguar também que a relação entre para-si e em-si é negativa, duplamente. Há sim constituição de mundo, mas o fenômeno não tem mais aquele ranço kantiano (noumeno), visto não mais haver assimetria entre o que é o fenômeno e aquilo que ele revela. Sartre está no campo ontológico no qual o ser se revela como é e, assim, subscreve de bom grado o dito heideggeriano: a ontologia somente é possível como fenomenologia. Husserl, que havia deplorado a analítica do Dasein, de fato exibe certo purismo em relação à ciência de essências que - sob suas mãos - nunca passou de uma busca infinda, sempre recomeçada, sempre visando novas depurações (inúteis à toda prova, visto que há sempre um resto - o mundo) do campo transcendental, sempre reinventando - a cada nova insinuação do mundo da vida - o lugar etéreo, o a-priori da correlação, o improvável sujeito transcendental puro. Husserl é idealista desde 1907 (A ideia da fenomenologia); ele também o era em 1901 (Investigações Lógicas)? E, mais, ele permanece idealista ao longo de seus textos inéditos? Sartre pretende partir do concreto total, e desde A Imaginação, marca posição em relação a isso: "o noema é um nada que não tem senão uma existência ideal, um tipo de existência que se aproxima do tipo de lékton estoico. Ele é somente o correlativo necessário da noese. [...]. Mas, se é assim, como então, uma vez feita a redução, distinguir o centauro que imagino da árvore em flor que percebo?" (Sartre, 1973, p. 109). E mais, $O$ Imaginário revela que "essa consciência livre - cuja natureza é ser consciência de alguma coisa [...] -, o que ela é senão simplesmente a própria consciência tal como ela se revela a si mesma no cogito?" (Sartre, 1996, p. 242). Partir do cogito com a condição de deixá-lo é, em grande medida, recusar a époché e manter a intencionalidade da consciência; a situação existencial será, nessa medida, o lugar de onde parte a ontologia fenomenológica.

Nesse pormenor, qual seja, recusar o conhecimento como ponto de partida, Sartre concorda totalmente com Merleau-Ponty; claro que, para Sartre, a espessura de mundo (âmbito pré-reflexivo) não pode comportar nenhum sentido prévio, sobretudo autóctone. Mas a frase a seguir, embora prefaciando a ontologia de Merleau-Ponty, bem que poderia figurar em EN: "O verdadeiro Cogito não define a existência do sujeito pelo pensamento de existir que ele tem, não converte a certeza do mundo em certeza do pensamento do mundo, e enfim não substitui o próprio mundo pela significação do mundo" (Merleau-Ponty, 2006, p. 9). É no mundo, e do mundo que Sartre pretende partir (concreto total); é a região ôntica (mundo) que deverá revelar sua estrutura ontológica, é da relação negativa entre em-si e para-si que $o$ Ser se faz mundo - relação fundamentalmente ontológica, jamais metafísica. Na conclusão de sua ontologia Sartre (2011, p. 757) é claro: 
A ontologia, portanto, limitar-se-á a declarar que tudo se passa como se o Em-si, em um projeto de fundamentar a si mesmo, se concedesse a modificação do Para-si. Compete à metafísica formar as hipóteses que irão permitir conceber esse processo como o acontecimento absoluto que vem coroar a aventura individual que é a existência do ser.

A consciência (Cogito situado) é ser-para-si, e enquanto tal se repete em todos os homens, mulheres e crianças; isso a faz ôntica e ontologicamente outra do ser-em-si, jamais do Ser (a consciência é). Ser falta-de-ser não tem, em absoluto, o mesmo sentido que nada ser: não se pode esquecer, o para-si é, "na medida em que existe nele algo do qual não é fundamento: sua presença ao mundo" (Sartre, 2011, p. 128). Homem-no-mundo, consciência-situada e Cogito são, assim, um e o mesmo para Sartre. Desconsiderar isso pode fazer dele um mau leitor de Husserl, ou um fenomenólogo equivocado; ademais, parece que é por desconsiderar a distinção proposta por Sartre, clara e precisa, entre metafísica e ontologia, que se pode falar de relação lábil entre o ser e o nada ou, mesmo, de ingenuidade de Sartre - seja ela realista ou idealista. Mas como mostrá-lo? Via negação, é claro! E, assim como os planos são dois (ôntico e ontológico), também dupla deverá ser a negação. Sartre admite, de saída, que há negatividade no mundo, ainda que a análise preliminar de Ser não tenha revelado - nele - nenhum nível ou gênero de negatividade. Ora, parece evidente que a negatividade seja da alçada do ser-para-si enquanto o em-si permanece absoluta positividade; mas essa afirmação se aplica ao âmbito ontológico, não ôntico: nesse o homem, ser-para-si, voltado negativamente ao Ser, revela um mundo de istos que ele não é. No mundo, o homem não é o cinzeiro à sua frente, tanto quanto não é o cigarro, nem o isqueiro, nem a mesa, nem a janela... ser para-si é não ser tudo aquilo a que ele está presente; e isso não se aplica somente aos objetos físicos dentre os quais o para-si se move, mas também a todas as ideias, emoções, etc. - mesmo o corpo - todo o mundo fenomênico, enfim, nasce desse movimento negativo que é o modo de ser-para-si. Nasce aí, mas permanece sustentado na absoluta positividade do Ser.

O questionamento de Barbaras (2005, p. 116) também é direto: "Na introdução de $O$ ser e o nada, que se confronta com a questão da fenomenalidade, Sartre recusa a versão husserliana da constituição, desenvolvida notadamente nas Ideias $I$, acusando Husserl de recair em uma forma de fenomenismo". De fato, as obras de Sartre que antecedem EN são marcadas pela preocupação de livrar-se da necessidade da redução fenomenológica; mas não se pode esquecer, Sartre repara também a noção de intencionalidade da consciência: ainda que em 1934, logo depois de sua ida a Berlim para estudar fenomenologia, ele se mantenha husserliano, vale lembrar que desde A Transcendência do Ego suas diferenças com Husserl se tornam flagrantes; mas, também desde aí é preciso considerar que Sartre fala em constituição do fenômeno. Em suas palavras,

A fenomenologia é um estudo científico e não crítico da consciência. O seu procedimento essencial é a intuição. [...]. Os problemas das relações do Eu com a consciência são, portanto, problemas existenciais. Husserl reencontra e apreende a consciência transcendental de Kant através da epoché. Mas esta consciência já não é um conjunto de condições lógicas, é um facto absoluto. Não é já também uma hipóstase de direito, um inconsciente flutuando entre o real e o ideal. É uma consciência real, acessível a cada um de nós a partir do momento em que executa a "redução". Mantém-se que é mesmo ela que constitui a nossa consciência empírica, essa consciência "no mundo", essa consciência com um "eu” (moi) psíquico e psicofísico. Nós cremos de bom grado, pela nossa parte, na existência de uma consciência constituinte (Sartre, 1994, p. 45-46).

Essa pode ser a fonte do caráter realista do existencialismo sartriano, afinal, nota-se que a discordância não é de modo alguma metodológica: Sartre é fenomenólogo e sua intuição original, aquela aventada no pitoresco encontro com Aron, o acompanha ao longo de sua estada em Berlim. Ora, combater o idealismo husserliano, ou kantiano, ou o idealismo em geral (Brunschvicg, Lalande, Meyerson) é fazer valer - existencialmente - as experiências individuais como fonte única de fenômenos e, como tal, do mundo (Sartre, 2005, p. 55-57). Se a fenomenologia é o estudo crítico da consciência, a ontologia de Sartre - ainda que pela via metafísica (ontologia) - busca mostrar que essa consciência não pode ser senão situada. Apesar da intuição genial de Husserl, aos olhos de Sartre, ele teria ficado prisioneiro de uma concepção por demais estreita das possibilidades de seu método. Também foi assim com Heidegger, que no fim é taxado pelo mestre de antropólogo; e o que dizer de Merleau-Ponty, caso ele fosse submetido ao mesmo tipo de lente? A fenomenologia da consciência intencional situada, do ver fenomenológico conforme o descreve Sartre, é sim metodologicamente tributária de Husserl; mas forçoso seria pensar que Jean Paul, um homem que nunca votou, que nunca fez parte de nenhum partido político, e que sempre fez questão de deixar sua marca em tudo que tocou, meramente assumisse o idealismo. Ele não o faz; terá por isso escrito ingênua e simploriamente - a filosofia que recusa o mundo que descreve? Não parece. Sartre admite que, como bem nota Barbaras (2005, p. 119), "é porque a consciência existe com sua própria negação" que ela pode reconhecer-se em seu ser; mas a negação é, na ontologia fenomenológica, aquela que perfaz, de um lado, o que é a consciência (revelação constituinte de istos), e de outro o que é o mundo (istos, que jamais coincidem com a consciência). É pela negação que o homem constitui fenômenos, mas é também assim que ele se faz; ele é liberdade: 
Uma liberdade absoluta que inventa a Razão e o Bem e que não tem outros limites além de si mesma e de sua fidelidade a si mesma, tal é finalmente para Descartes a prerrogativa divina. Por outro lado, porém, não há nessa liberdade mais do que na liberdade humana, e ele tem consciência, ao descrever o livre-arbítrio de Deus, de não ter feito senão desenvolver o conteúdo implícito da ideia de liberdade. [...]: o homem é o ser cujo surgimento faz com que um mundo exista (Sartre, 2005, p. 299-300).

Note-se que, pelo homem, o nada é levado ao ser e, com isso, tem-se o mundo fenomênico; o nada, que evidentemente não tem ser, é nadificado pela consciência - mas isso a partir do Ser (o ser-para-si é, ainda que seja o que não seja e não seja o que é). Se o Deus cartesiano cria o mundo a partir do nada, o homem também cria seu mundo negando Ser.

Isso posto, cabe voltar-se para a negação. $\mathrm{Ou}$ seria mais justo dizer negações? Sim, pois - mostra Sartre - há falta e é por ela que o mundo chega ao ser; ou, dito de outro modo, é pelo para-si que $o$ nada é levado ao ser e, assim, revela um mundo de istos. Mas como se dá essa modalidade de constituição senão pela negação? Um exemplo pode ajudar: no âmbito mundano a consciência intencional dirige-se àquilo que lhe falta; seria desejo (vontade), como pretende Barbaras? Não parece. Primeiro, desejo que a água dentro do copo à minha frente esteja gelada; mas independentemente do que eu queira, ela permanece à temperatura natural. Ora, a impossibilidade de deformar o fenômeno que se revela em função da vontade mostra, de modo inequívoco, que o ser é transfenomenal; senão, como falar em mundos ideais (matemática, fantasia, etc.), tendo colocado entre parênteses o mundo que eu posso estreitar? Ademais, fica patente que - ainda que seja pela intuição categorial - fenomenologicamente são estados de coisas que se revelam, em sua contextura e qualidades próprias. Sim, Sartre parte do Ser e a ele retorna, mas isso se deve à impossibilidade, demasiadamente humana, de nada ser: o para-si não é o que é. Ainda assim, mesmo morna, o copo e a água que o preenche não são eu, mesmo que somente possam ser para-mim (mundo fenomênico, jamais fenomenismo): o ser-para-si é também transfenomenal. E como seria se ambos os movimentos, aquele do para-si ao em-si, e novamente do em-si ao para-si, fossem considerados em conjunto? De fato, se há passagem do âmbito ôntico ao ontológico é porque esse é o fundamento daquele. O Ser é o fundamento tanto do em-si quanto do para-si, ou seja, cada homem é também um fenômeno no mundo: seu ser-para-outro o revela a contento. Ainda, não se pode esquecer que a obra de Sartre é uma ontologia, ou seja, ele o faz a partir da revelação de modos de ser; e, uma vez que essa ontologia é fenomenológica, o que se apresenta no mundo como fenômenos de homens e objetos é um e o mesmo ser: aquele que, num ato de sacrifício se faz para-si e busca seu fundamento, doutrina central de EN. O projeto ontológico de Sartre é de uma ontologia do ser-no-mundo; ou homem-no-mundo, o que dá no mesmo. E, no mundo, o que se encontram são homens e coisas, e o homem não coincide consigo - é para-si -, donde se possa dizer que os objetos são em-si; e se a característica humana por excelência é jamais coincidir consigo, pode-se também admitir que, diferentemente do homem, os istos coincidem com seu ser. Dessa constatação banal, Sartre desenvolve um modelo de relação, duplamente negativa, do para-si em relação ao em-si, pela qual faz-se, de um lado, homem (pela negação de istos) e, doutro, pela auto-negação da consciência humana em seu movimento negativo em relação aos istos, o mundo. E todo esse complexo resguarda um princípio pétreo da filosofia da liberdade: homem e mundo não são separáveis de fato (quiçá de direito), existem $a$ partir do outro. Desse intrincado jogo ontológico, o filósofo retira ainda outra consequência: ele se pergunta por que o para-si é negação do em-si, ou, $o$ que busca a consciência com seu movimento ininterrupto? E responde: parar, ou seja, coincidir consigo mesma. Todavia, e ele mesmo o mostra, isso é impossível, visto que o homem é finito e seu projeto almeja a infinitude, a eternidade, o Ser-total ou a Totalidade mesma. Deus, enfim. Isso não escapou a Barbaras, na medida em que aquilo "que falta ao para-si e que Sartre nomeia 'valor', é a síntese do em-si e do para-si” (Barbaras, 2005, p. 127); valor livremente inventado, faltou dizer. Paradoxal que, no caso da filosofia de Sartre, o a priori da correlação tenha se revelado como existência: ser homem é, pela intencionalidade, ser-consciência-mundo, ao passo que o mundo é o lugar-de-ser-consciência. Um lugar sui generis na medida em que - como antecipou Merleau-Ponty - trata-se de um buraco que se cava na medida em que se enche; mas, declaradamente, não um buraco sem fundo (grundloss); o Nada, que adentra a absoluta positividade, Ser, de fato levaria a filosofia de Sartre às paragens metafísicas - mas isso, e Sartre sabe, é impossível fenomenologicamente. Mesmo assim tem-se o Ser que se revela como mundo, repleto de seres em-si e para-si; e, aí, desse ponto de vista, a relação lábil entre o Ser e o Nada precisa mesmo ser denunciada. Ora, é para isso que Sartre reserva o termo metafísica. Todavia, o filósofo fala de negação, e será no mais profundo para-si que nada se revela: ele nasce do coração do ser, ele é o modo de ser-para-si, é por ele - porque o nada irisa na superfície do Ser - que o mundo acontece ao ser.

Em sua conferência de 1946, Sartre admite a austeridade do existencialismo: "O que queremos dizer é que um homem nada mais é do que a série de empreendimentos, que ele é a soma, a organização, o conjunto das relações que constituem esses empreendimentos" (Sartre, 1978, p. 14); nenhuma mazela, assim como nenhuma vitória humana vai além daquilo que cada homem faz. Isso é revelado em toda a obra de Sartre, em seu teatro e literatura, em suas intervenções públicas e, claro, em sua filosofia. De fato, ali o homem é responsabilizado por todo o mundo, mas na exata medida em que o mundo é inteira construção sua. A partir do Ser, afinal se Deus pode criar do nada, o homem cria 
por sua livre negação do ser. E a água que permanece, morna, dentro do copo à sua frente, mostra isso; mas até mesmo voltar-se para o copo vai depender de sua absoluta liberdade. Afinal, se a fenomenologia revelou que o fenômeno tem infinitas visadas possíveis, caberá a cada homem trazer ao mundo aquilo que, em vista de seu projeto de ser (escolha original), mais lhe aprouver. Desse modo, para Sartre, ser-homem é ser consciência: o ser-para-si, enquanto modalidade ontológica do ser-humano-consciente (negação do ser-em-si), é o modo de ser-humano no mundo que, enquanto se faz, faz mundo. O movimento, duplamente negativo, aparece separado em EN; por razões didáticas, Sartre parte somente do homem no acontecimento absoluto: ser-para-si é fazer-se nada, levando o nada ao coração do ser, trazendo assim o ser ao mundo; o para-si afirma-se nada ante à totalidade do Em-si. De um só golpe, o para-si arrancou-se do ser, fazendo dele seu outro - essa é a negação interna; mas ela não se realiza senão pela negação de istos, ou seja, via negação externa, fazendo com ela um único e mesmo ato negativo (acontecimento absoluto enquanto escolha original). O para-si é negação do ser, ele se faz nada e, como contrapartida, o ser é trazido ao mundo, como mesa, cadeira, copo, como Deus, anjos, Totalidade, como desejo, medo, amor, como História, Sociedade, Ética; mas o que é essa totalidade-totalizante senão o mundo? Assim, o mundo é essa estranha região entre o ser e o nada, provocado pela negação empreendida pelo para-si ao ser (a si mesmo) e mantida - considerando-se aí, do ponto de vista do homem - pela contingência do ser. É isso que se pode chamar de liberdade em Sartre: ela se realiza ao mesmo tempo enquanto negação que se afirma enquanto nega o Ser; por esse movimento, o fenômeno é ser trazido ao mundo: o homem não é essa cadeira, nem essa mesa, nem nenhuma das realidades que ele encontra no mundo. Ele é ser-para-si (si-mesmo, consciência) que se faz pela via negativa; ele é impossibilidade de repouso em objeto algum. O resultado desse movimento negativo (visto que cada um dos homens é negação) é o mundo em seus istos: o para-si, como resultado de sua negação de coincidência com o ser e consigo mesmo, nega-se a coincidir com isso que ele encontra, e o único modo de não o ser é afirmando-o. $\mathrm{O}$ fenômeno, sobretudo em Kant, resume-se à mera aparência, justificação do idealismo como única rota fenomenológica. O fenômeno é, de fato, aparência de ser no mundo produzida pelo movimento que o para-si é; e isso não o oculta, como pretendeu a tradição, mas é a possibilidade de sua revelação. No princípio não poderia estar a razão - ou o entendimento e suas categorias -, e o único nome sartrianamente aceitável para fundar tal fenômeno é a liberdade. Por ela, negativamente, tem-se homem e istos (coisas) sendo, ambos, de mesma estirpe, mundanos; ancorados no ser, pois de outro modo nada seriam, mas ainda assim dependentes de certa dose negativa para - ambos - frequentarem o mundo.

É pela negação (vista de suas duas faces), por sua existência mesma que o homem se faz para-si enquanto nega istos; e, em sua jornada, ele terá para trás de si (seu passado) tudo aquilo com o que ele não pode coincidir. O movimento negativo de ser-homem-no-mundo deixa como rastro o próprio mundo vivido, e como existente um ser para o qual os fenômenos e outros homens (ser-para-outro) se revelam. Há ser, ele se mostra fenomenicamente em-si e para-si (identidade, por oposição ao movimento negativo para-si); o mundo resulta do movimento negativo de ser. Nem idealista nem realista, pois se o mundo resulta da negação enquanto fenômeno, o fenômeno é a maneira do ser vir ao mundo: é ele, o Ser mesmo, que se mostra e permanece quando o para-si nega-se a se identificar com uma sua faceta qualquer, fazendo-se outro do ser. Esse processo revela para a consciência a contingência do Ser, vivida como objetos imediatos (mesa, cadeira, copo, etc.) e ideias (centauro, humanidade, verdade, etc.); ainda, não se trata de mera descrição da mundanidade do mundo, na medida em que, diferentemente do Dasein, ser-para-si é ser homem-consciente-no-mundo. A consequência imediata dessa ontologia não poderia passar despercebida: de fato, há "no coração do para-si uma falta irredutível, correlativa do ek-stase passivo do em-si para quem o para-si advém, Sartre dá conta da correlação fenomenológica como relação constitutiva, preservando a diferença dos termos em relação, co-dependência na separação” (Barbaras, 2005, p. 131); mas, nem por isso, cumpre concluir que a realidade humana seja desejo: ontologicamente, trata-se, antes, de condenação, na medida em que "Ser livre é estar condenado a ser livre" (Sartre, 2011, p. 183). O desejo, por sua vez, somente poderá apresentar-se (ser eleito) em situação; ou, é assim que se entende aqui as palavras do filósofo, pelas quais há duas modalidades negativas, interna e externa: ser-para-si é, internamente, 'arrancar-se negativamente do ser' e promover a negação externa de istos, o que ao mesmo tempo em que leva o nada ao coração do ser, traz o ser ao mundo. Mas, ao mesmo tempo, não outorga ao em-si tudo aquilo que Sartre atribuiu ao Ser: o homem é, e, sendo, leva seu nada de ser ao Ser, revelando o mundo de istos. Assim, "o Em-si só tem uma dimensão do ser; mas a aparição do nada como aquilo que é tendo sido no coração do ser complica a estrutura existencial, fazendo surgir a miragem ontológica do Si” (Sartre, 2011, p. 192). Ou seja, a negação interna é aquela pela qual o ser-para-si - pela negação de coincidir-se com qualquer uma das facetas do que se lhe apresenta - arranca-se da totalidade do Ser. Assim, longe das verdades apodíticas transcendentais, Sartre chama esse fato acontecimento absoluto. É pela negação interna, aquela que altera os seres que se negam, que o nada vem ao mundo; mas será pela negação externa, aquela que o para-si nega istos sobre um fundo de mundo, que ele pode realizar seu projeto de ser. ${ }^{5}$ Mas ser o que? Ontologicamente

$5 \quad$ Em EN, Sartre analisa o desejo a partir da sexualidade. E, quando se pergunta sobre o que é desejado, tem-se que "no desejo, o corpo, em vez de ser somente a contingência da qual foge o Para-si rumo a possibilidades que lhes são próprias, converte-se ao mesmo tempo no possível mais imediato do Para-si; o desejo não é somente desejo do corpo do Outro: é, na unidade de um mesmo ato, o projeto não teticamente vivido de atolar-se no corpo; assim, o derradeiro grau do desejo poderá ser o desvanecer, enquanto derradeiro grau de consentimento ao corpo. [...]. De fato, é um apetite voltado para o corpo do Outro, vivido como vertigem do Para-si ante seu próprio 
ser-em-si-para-si (Deus), está claro; e onticamente, o que deseja o ser-para-si? Parece que, sendo isso a liberdade, cada homem será seu projeto (e não alguma sorte de desejo), que também matizará o que é cada homem no mundo.

\section{Barbaras, Sartre e a falta ontológica vivida como desejo}

O homem, deus faltado, arranca-se do Ser; essa arrancada faz dele ser-para-si e, enquanto tal, desde sempre em relação com o em-si que ele encontra fora de si por assim dizer. Mas também em relação a si: nada o separa de si mesmo senão aquilo que ele é, ou seja, consciência (para-si); ser homem é aniquilar-se sobre aquilo que nega. Ser-para-si é fazer-se, e "as qualidades negadas são precisamente o que há de mais presente ao Para-si; é delas que o Para-si toma sua força negativa e a renova perpetuamente" (Sartre, 2011, p. 238). A negação é, pois, "um fator constitutivo de seu ser, porque este deve estar lá adiante, fora de si, sobre elas, deve sê-las para negar sê-las" (Sartre, 2011, p. 238). A ontologia de Sartre é revelada pela condição ôntica e, assim, tem que a negação externa é aquela que é

[...] correlata à negação interna, radical e ek-stática que eu sou. Isso explica o caráter ambíguo do mundo que se desvela ao mesmo tempo como totalidade sintética e coleção puramente aditiva de todos os "istos". Com efeito, na medida em que o mundo é totalidade que se desvela como aquilo sobre o qual o Para-si tem-de-ser radicalmente seu próprio nada, o mundo se oferece como sincretismo indiferentista. Mas, na medida em que esta nadificação radical está sempre Para-além de uma nadificação concreta e presente, o mundo parece sempre prestes a se abrir como uma caixa para deixar aparecer um ou vários "istos" que já eram - no âmago de indiferenciação do fundo - aquilo que são agora como forma diferenciada (Sartre, 2011, p. 246).

Em resumo, o homem é livre enquanto negação que se desdobra em duas modalidades: aquela que o constitui, de seu lado, e ela mesma enquanto resultado, aquela que faz com que haja mundo; entretanto, como se passa no caso do 'outro'? A negação interna faz com que haja para-si, a negação externa promove relações de istos no mundo, ou seja, desvela o mundo; mas "se, com efeito, a relação fundamental entre meu ser e o ser do Outro se reduzisse à relação entre meu corpo e o corpo do Outro, seria pura relação de exterioridade. Mas a minha relação com o outro é inconcebível se não for uma negação interna” (Sartre, 2011, p. 427). Numa mesma frase, tem-se que o homem é o Ser já paradoxal: em-si (corpo visto) e, no mesmo ato, para-si (corpo vivido conscientemente); arrancar-se do ser é fazer ruir a massa informe (ser bruto indiferenciado) em istos mas, ao mesmo tempo, manter

corpo; e o ser que deseja é a consciência fazendo-se corpo" (Sartre, 2011, p. 483-484). a totalidade do ser como fundo; e tudo isso ante o olhar do outro (demais homens, e Outro, no sentido institucional). Desfeita a confusão entre os âmbitos ontológico e ôntico, a pergunta direcionada por Barbaras pode - enfim - ser respondida: "Como pode haver desejo, se o desejado não pode ser de alguma maneira?" (Barbaras, 2005, p. 133). A questão revela a ingenuidade de Sartre quando tomada do ponto de vista exclusivo da fenomenologia pura, afinal o desejo de ser-em-si-para-si (ser Deus) jamais poderá ser realizado; todavia, nesse jogo duplo de negações proposto por Sartre, será a falta ontológica - e não alguma sorte de desejo - que jamais poderá ser preenchida. Não é porque o homem jamais será Deus que seus projetos de ser homem-no-mundo (ônticos, existenciais) malogram; ao contrário da consequência aventada por Barbaras, caso se considere a distinção em planos - coextensivos, interdependentes - tem-se que o motor dos projetos ônticos é de base ontológica: ser homem é ser liberdade; ele escolhe e é condenado a escolher. Sua escolha original (negação interna) será reeditada a cada escolha presente (negação externa); a falta ontológica será a razão dos projetos existenciais. E se determinado homem deseja ser professor de filosofia, não poderá ele sê-lo ao final de seus estudos? Ora, onticamente os projetos são sim realizáveis; o problema passa a ser de outra ordem: o homem, ser-para-si, não poderá jamais ser professor, tal qual o cinzeiro é cinzeiro. $\mathrm{E}$, por isso, ainda que acompanhando o professor Barbaras quando de sua constatação de que o desejado é irrealizável, é preciso dizer que ele o é em definitivo - o homem permanecerá um deus faltado, que mesmo sem jamais realizar o em-si-para-si, existirá tentando ${ }^{6}$.

Mas o homem realiza sim seus projetos. O que lhe é impossível é realizá-los em definitivo. A menos que a morte interrompa algum projeto em curso, cada um deles será, irremediavelmente, o solo de um novo projeto; o aluno que termina sua graduação se fez graduado, mas, nem por isso, é graduado como um cachimbo é um cachimbo. Ele permanece possibilidade, e sua graduação ou bem o levará ao mercado de trabalho ou à pós-graduação - vencido o desejo do primeiro nível, é daí, de seu ser-graduado-no-mundo, que ele vai escolher seu novo projeto. O homem é situado, e será sua situação que vai apontar aquilo que ele vai encontrar em seu futuro. E tudo isso pode ser alcançado no ser-para-outro, pois, ainda que esse homem, agora graduado que se encaminha à pós-graduação, não possa meramente identificar-se com o ser-homem-graduado-no-mundo (ele é liberdade), ele assim o será para o olhar alheio. $\mathrm{Ou}$, dito de modo mais preciso, o ser-social de cada homem faz-se também pela negação de outras liberdades; repete-se a dupla negação:

Só que esta dupla negação, em certo sentido, é $6 \quad$ As psicanálises existenciais levadas a cabo por Sartre revelam justamente isso: Flaubert, ante à determinação mundana de ser idiota, fez-se um dos maiores escritores da França; Genet, o ladrão aos dez anos, fez-se poeta; ainda, Baudelaire, que passa sua existência quase que obcecado por realizar a totalidade que vira nos olhos de sua mãe (quando do segundo casamento de sua mãe, quando ele tinha sete anos), escreve os mais belos poemas do amor irrealizado (e irrealizável). E Mallarmé, sua primeira investida nesse projeto; pela ordem, Sartre, 1952; 1963; 1971; 1986. 
destruidora de si própria: ou bem, com efeito, faço-me não ser certo ser, e então este é objeto para mim e perco minha objetividade para ele, caso em que o Outro deixa de ser Outro-eu, ou seja, o sujeito que me faz ser objeto pela denegação de ser eu; ou bem este ser é efetivamente o Outro e se faz não ser eu, mas, em tal caso, converto-me em objeto para ele, e ele perde sua objetividade própria. Assim, originariamente, o Outro é o Não-eu-não-objeto (Sartre, 2011, p. 364).

E se é assim que o outro me aparece, é de se supor que também assim eu apareça a ele. Não é por acaso que, no arremedo de analítica existencial de Descartes, Sartre revele o caráter produtivo da negação: vale lembrar que o Deus cartesiano cria positivamente do nada, por afirmação, ao passo que o homem cria e cria-se pela negação, e assim, ao levar a falta ao seio do Ser (positividade), faz com que ele se revele fenomenicamente no mundo. Desse modo, o problema parece muito mais ligado à concepção correta - ou melhor, ortodoxa - da fenomenologia. Em conformidade com o projeto husserliano, Barbaras (2005, p. 135) mostra que "tudo repousa sobre isso, que se poderia nomear a dissimetria ontológica da fenomenologia sartriana, que manifesta uma forma de ingenuidade, isto é, de submissão à atitude natural”. Que seja, mas em que medida Sartre pode ser considerado ingênuo porque não encampou a fenomenologia como ciência de essências que, por sucessivas purificações, pretende descrever o a-priori da correlação? Ora, em sua ontologia, o filósofo não considera o desejo senão como uma conação, que figura ao lado do instinto, da vontade e do hábito. Ou, dizer que "para comprovar que a realidade humana é falta, bastaria a existência do desejo como fato humano" (Sartre, 2011, p. 137), não tem, em absoluto, o mesmo sentido que reduzir (ou enformar) aquilo que falta ao para-si com aquilo que cada homem deseja presentemente no mundo. Ademais, o projeto de ser que nasce da falta originária, não poderia apresentar seu objeto senão como possibilidade; afinal, é daí que se pode afirmar que ser homem é ser liberdade. Doutro modo, Sartre teria que escrever pela cartilha husserliana, e seu objetivo de, partindo do concreto total, chegar ao concreto absoluto seria impossível. A contrapartida não faz melhor, na medida em que sua filosofia seria reduzida a um psiquismo bastardo, rejeitado pela psicologia e causa de piada nos meios transcendentais. Assim, cabe insistir um pouco no tema da negatividade.

A descrição da constituição do fenômeno na filosofia de Sartre, da maneira como se apresenta no texto de Barbaras, parece incompleta. ${ }^{7}$ De fato, caso

\footnotetext{
7 Essa constatação pode ser indicada na argumentação tecida pelo filósofo nas pp. 118-20 de seu texto; precisamente, Barbaras (2005, p. 119) afirma que "com efeito, não há verdadeira mentira a si, tal que eu enquanto enganado possa saber isso que eu ignoro enquanto enganado, que se a consciência é, por natureza, aquilo que ela não é isso que ela é: é porque a consciência existe como sua própria negação que ela pode se conhecer sob o modo de esquecimento, captar-se sob o modo de fuga". Todavia, se a negação for dupla como pretende Sartre, ela será o modo universal de relação da consciência, seja com o Ser, seja com istos, seja com outras pessoas e, mais ainda, consigo mesma.
}

seja desconsiderada a démarche filosófica e os interesses que movem a filosofia da liberdade, sobretudo que a negação é dupla, o que se tem é que "então Sartre introduz no princípio, num modo finalmente realista, uma separação entre o ser e o fenômeno" (Barbaras, 2005, p. 136). Assim, admite-se, de bom grado, que a filosofia de Sartre não tem o escopo transcendental da dita fenomenologia verdadeira; todavia, o mesmo não poderá ser dito dessa pretensa separação entre ser e fenômeno. De início, vale lembrar que a situação na qual o para-si é lançado não tem a mesma ingenuidade do realismo moderno: trata-se de análise de condutas do homem no mundo; mas mais do que isso, vale dar voz àquilo que Sartre entende por fenomenologia:

O fenômeno continua a ser relativo porque o “aparecer” pressupõe, em essência, alguém a quem aparecer. Mas não tem a dupla relatividade da Erscheinung kantiana. O fenômeno não indica, como se apontasse por trás de seu ombro, um ser verdadeiro que fosse, ele sim, o absoluto. O que o fenômeno é, é absolutamente, pois se revela como é. Pode ser estudado e descrito como tal, porque é absolutamente indicativo de si mesmo (Sartre, 2011, p. 16).

Indicativo de si mesmo, todavia relativo à consciência intencional, o mundo fenomênico revela-se ao homem pelo mesmo ato que é constituído. Sartre tem em seu auxílio condutas negativas humanas que revelam, ao mesmo tempo, a totalidade e positividade do Ser e sua revelação mundana numa infinidade de istos; ou, assim como seria para Heidegger, em Sartre (2011, p. 19-20): "O existente é fenômeno, quer dizer, designa-se a si como conjunto organizado de qualidades. Designa-se a si mesmo, e não seu ser. O ser é simplesmente a condição de todo desvelar: é ser-para-des-velar, e não ser desvelado". A intuição primeira de Sartre, quando de seus estudos na Alemanha, era sim de que a fenomenologia fosse uma filosofia realista. Husserl foi, à primeira hora, o mentor desse realismo, que no desenrolar de seu pensamento mais conhecido (excetuando-se o inéditos) $^{8}$, acaba em 1907. Assim, a pretensa ingenuidade sartriana teria como nascedouro a indecisão própria do criador da fenomenologia, que - sob alegação de colocar entre parênteses o estar aí adiante das coisas - acaba, para Sartre, lidando com espectros ônticos (mundo reduzido). E, ao fazê-lo, repete a dicotomia vivida entre Kierkegaard e Hegel: de acordo que não há outro ponto de partida senão a subjetividade (algo que Heidegger discorda), mas ela deverá sempre tender ao a-prio8 A respeito, pode-se dizer que Sartre partilha com Merleau-Ponty e, quiçá Heidegger, sua ideia da fenomenologia "É a ambição de uma filosofia que seja uma 'ciência exata', mas é também um relato do espaço, do tempo, do mundo 'vividos'. É a tentativa de uma descrição direta de nossa experiência tal como ela é, e sem nenhuma deferência à sua gênese psicológica e às explicações causais que o cientista, o historiador ou o sociólogo dela possam fornecer, e todavia Husserl, em seus últimos trabalhos, menciona uma 'fenomenologia genética' e mesmo uma 'fenomenologia construtiva'. Desejar-se-ia remover essas contradições distinguindo entre a fenomenologia de Husserl e de Heidegger? Mas todo Sein und Zeit não nasceu de uma intuição de Husserl?" (Merleau-Ponty, 2006, p. 1-2). A mesma pergunta não poderia ser hoje, passados mais de meio século, também aplicável a Sartre e ao próprio Merleau-Ponty? 
rismo e rejeitar a experiência cotidiana? Não é assim em todo o Husserl, e se coube ao filósofo dinamarquês, contra Hegel, afirmar a paixão sofrida, mal comparando, cabe a Sartre recuperar o homem em sua existência a partir de Husserl. E a partir disso não permitir que toda a riqueza fenomenológica que é a aventura individual (ser-para-si-no-mundo) seja diluída noutra espécie de salmoura mal-cheirosa, dessa feita não o Espírito, mas o campo transcendental absolutamente purificado.

É no mundo, do mundo e pelo mundo que, via ontologia fenomenológica, o Ser se revela. É porque o homem não pode existir sem escolher, visto não escolher ser ainda uma escolha, que se pode falar em liberdade. É porque, por mais claro e distinto que se pretenda, no mundo todo fenômeno apresenta infinitas possibilidades de visadas, que Sartre conclui que ser-homem é ser-negação. O existencialismo é, para nossos dias, um fenômeno aberto a interpretações, e que apresenta também infinitas visadas possíveis. Ora, para Sartre (2011, p. 589),

Seria inútil imaginar que a consciência pudesse existir sem o dado: seria então consciência (de) si mesmo como consciência de nada, ou seja, o nada absoluto. Mas, se a consciência existe a partir do dado, não significa em absoluto que o dado a condicione: a consciência é pura e simples negação do dado, existe como desengajamento de certo dado existente e como engajamento no rumo de certo fim ainda não existente.

Está claro que as sucessivas depurações do campo transcendental não terão espaço em sua filosofia, visto essa empreitada, além de lhe parecer inócua, beirar o sem-sentido de discursar sobre nada. Afinal, nada mais distante que as noções de homem enquanto ser-para-si e sujeito transcendental. Primeiro, não se trata de conhecer, mas de ser; segundo, o processo de purificações sucessivas terá, para Sartre, um final previsível: consciência de si sem o mundo, ainda que ele esteja disponível entre parênteses, assemelha-se ao nada elevado à segunda potência. De novo, e ainda que o projeto sartriano seja diferente daquele de Husserl, é preciso lembrar que não somente em Husserl, mas todo o idealismo carrega em seu coração a recusa de qualquer conduta humana no mundo que não seja cognoscitiva. E ainda que isso seja um equívoco desde 1907, o fato é que Sartre credita a Husserl a possibilidade da renovação de todo o conhecimento; mas, para isso, "o primeiro passo de uma filosofia deve ser, portanto, expulsar as coisas da consciência e restabelecer a verdadeira relação entre esta e o mundo, a saber, a consciência como consciência posicional do mundo" (Sartre, 2011, p. 22). E essa divergência de Husserl é, em certa medida, paralela às divergências entre Heidegger e seu mentor e, claro, razão da releitura da fenomenologia conforme a proposta de Merleau-Ponty (prefácio da fenomenologia). ${ }^{9}$ Conta a história da filosofia que, de bom

9 "O verdadeiro Cogito não define a existência do sujeito pelo pensamento de existir que ele tem, não converte em certeza do mundo em certeza do pensamento do mundo e, enfim, não substitui o próprio mundo pela sig- grado, Sartre incorpora em seu existencialismo a intencionalidade da consciência; decorre daí que sua filosofia, porque recusa-se a reduzir o mundo, não é fenomenológica? Ou seria mais acertado dizer que Sartre, embora servindo-se do aparato epistemológico da fenomenologia, recusa-se a pensar os fenômenos como mera significação? Afinal, a liberdade se revela pela náusea, conduta humana no mundo, que não exige nenhuma predisposição metafísica; de outro lado, a epoché - declaradamente caminho para superar a atitude natural - desnaturaliza o mundo. O a priori da correlação, conforme revelado por Sartre, extrapola em muito a esfera dos fenômenos reduzidos: a fenomenologia, via Heidegger, Sartre e Merleau-Ponty, porque abandona a prerrogativa do conhecimento e volta-se para o Ser, torna o campo investigativo fenomenológico muito mais ancho, podendo nele caber tanto a analítica do $\mathrm{Da}$ sein quanto a fenomenologia da percepção; e, claro, a filosofia da liberdade, da consciência-livre-situada.

O mundo é humano. Uma constatação banal, pode parecer, mas Sartre encara o humanismo de modo radical: não se trata de conhecer o mundo, mas de construir o real peça a peça. Por real entenda-se tanto o para-si quanto o em-si (e para-outro) objeto adequado à ontologia fenomenológica; qualquer um dos dois em separado será abstração. Isso poderia gerar a aporia de um mundo que já é encontrado pronto e, ao mesmo tempo, precisa ser refeito a cada instante. Mas é justamente isso: trata-se da condição humana que, ainda que seja contingente sua existência tanto quanto é contingente sua situação, é necessário que o homem seja no mundo. Não se trata de pensar idealmente, e reduzir o mundo ao pensamento do mundo, nem de - ingenuamente - negar a camada constituinte de todo fenômeno, o que de fato seria realismo ingênuo. Sobre isso, Sartre é preciso:

Dizer que há ser e nada, contudo, é operar total metamorfose, posto que não há ser exceto para um Para-si. Não é em sua qualidade própria que o ser é relativo ao Para-si, nem em seu ser, e com isso escapamos ao relativismo kantiano; mas é relativo em seu "há", uma vez que, em sua negação interna, o Para-si afirma aquilo que não pode se afirmar e conhece o ser tal como é, quando o "tal como é" não poderia pertencer ao ser. Nesse sentido, o Para-si é presença imediata ao ser e, ao mesmo tempo, desliza com distância infinita entre ele mesmo e o ser. Pois o conhecer tem por ideal o ser-o-que-se-conhece, e, por estrutura originária, o não-ser-o-conhecido. Mundaneidade, espacialidade etc., nada mais fazem do que expressar esse não ser. Assim, encontro-me por toda parte entre mim mesmo e o ser, como um nada que não é o ser. O mundo é humano (2011, p. 285ss).

Homem no mundo, que se arranca da positividade do ser ao inserir nada que o separa de si

nificação do mundo" (Merleau-Ponty, 2006, p. 9). 
mesmo e, assim, promove a destotalização da totalidade; mas, nem por isso o homem deixa de ser, afinal ele é lançado numa situação mundano-concreta. Um círculo vicioso, pelo qual o homem constitui um mundo que já encontra pronto? De modo algum. Em suas psicanálises existenciais, Sartre volta-se para à infância e, curiosamente, causou estranheza sua lembrança de que todo homem foi criança. ${ }^{10}$ Em suas reflexões sobre Flaubert, ele insinua a descrição da sensibilidade infantil e mostra que, desde aí, a mesma relação negativa se instaura. O acontecimento original, o brotamento desse nada no coração do ser não pode, em termos absolutos, ser explicado pela ontologia - seria preciso uma decisão metafísica para tal. Mas, do âmbito existencial (ôntico), como negar o absurdo de que nascemos e de que morremos? A negação externa ou presente resume-se a constituir relações entre istos; já "no caso da negação interna Para-si-Em-si, a relação não é recíproca, e sou ao mesmo tempo um dos termos da relação e a própria relação" (Sartre, 2011, p. 760). Se a consciência não tem um fora ou um dentro, ela existe promiscuamente no mundo, que recusa ser porque é, e recusa sê-lo porque ela mesma o faz, mas o faz na exata medida em que a consciência revela o Ser - nunca de maneira exaustiva, porém sempre fazendo vir ao mundo algum aspecto do ser que ainda permanecia obscuro (ainda que sempre tenha estado aí).

O mundo é público. Enquanto certa fenomenologia pretende livrar-se do mundo (e de tudo que pode ser considerado mundano) para melhor conhecê-lo, Sartre não permanece prisioneiro desse último homem que se apresenta como sujeito transcendental. Sujeito que não morre, que não sente dor, que não sua nem sofre - que não existe, enfim; o homem, por sua vez, não pode ser senão pelo outro, aquele que "deve aparecer ao cogito como não sendo eu” (Sartre, 2011, p. 326). Mais uma vez, é preciso levar em consideração que a negação pode ser concebida de duas maneiras: "ou bem é pura negação externa e irá separar o Outro de mim tal como uma substância de outra substância - nesse caso, toda captação do Outro é, por definição, impossível” (Sartre, 2011, p. 326), caso que justificaria admitir, com Merleau-Ponty, que a ontologia de Sartre não vai além da nega-intuição do nada, ou com Barbaras, nega-intuição do ser. Todavia, a relação negativa do para-si com o Ser e com outros para-sis é interna, "o que significa conexão sintética e ativa de dois termos, cada um dos quais se constitui negando ser o outro. Esta relação negativa será, portanto, recíproca e de dupla interioridade" (Sartre, 2011, p. 326). Dupla interioridade, quando se trata da rela10 "Ser Para-si é ser nascido. Mas não cabe fazer depois questões metafisicas sobre o Em-si do qual nasceu o Para-si, tais como: 'De que modo havia um Em-si antes do nascimento do Para-si?'; 'Como o Para-si nasceu deste Em-si e não de outro?' etc. Todas essas questões não levam em conta que o passado em geral só pode existir pelo Para-si. [...]. Nesse sentido, o Para-si, na medida em que seu surgimento ao ser faz com que exista um mundo de copresenças, também faz aparecer seu 'antes' como copresente a Em-sis em um mundo, ou, se preferirmos, em um estado de mundo que passou. De sorte que, em certo sentido, o Para-si aparece como nascido do mundo, pois o Em-si do qual nasceu está em meio do mundo como copresente passado entre copresentes passados: há surgimento, no mundo e a partir do mundo, de um Para-si que não era antes e que nasceu" (Sartre, 2011, p. 195-196). Ainda, ver Da Silva, 2018. ção entre para-sis, mas também originária em relação ao Ser: ainda que um escândalo, é um fato que a consciência reflexiva surge num corpo - que é em-si -, mas que leva consigo a total possibilidade de abertura ao mundo (liberdade). Esse homem que, nas palavras de Merleau-Ponty, precisa reaprender $a$ ver o mundo, faz-se livre e negativamente em relação ao mundo no qual surge, mantendo com $o$ Ser (via istos) e com os demais homens uma relação de interioridade, ainda que negativa. Enfim, do mesmo modo que há uma passagem da negação interna à negação externa, há o plano da pré-reflexão e o plano reflexivo, cada um deles correspondendo a um momento dessa mesma consciência: o bebê e parte da infância são consciência, é claro, mas ainda não reflexiva, donde o caráter ambíguo da escolha original. O acontecimento absoluto, a consciência intencional é, por sua vez, o aparecimento da consciência de consciência, que configura a passagem do não saber ao saber de si. "Assim, não há primazia da reflexão sobre a consciência refletida, esta não é revelada a si por aquela. Ao contrário, a consciência não reflexiva torna possível a reflexão: existe um cogito pré-reflexivo que é condição do cogito cartesiano" (Sartre, 2011, p. 24). É do mundo vivido que nasce o pensamento do mundo, e tentar livrar-se do mundo para entender suas estruturas profundas aparece a Sartre como non sense.

\section{Conclusão}

Para concluir, pode-se dizer que as questões levantadas por Barbaras indicam claramente as razões pelas quais caberia inferir a ingenuidade da ontologia fenomenológica de Sartre. Todavia, caso a mesma indagação leve em conta a duplicidade do movimento negativo proposto na ontologia fenomenológica, o resultado não parece ser o mesmo, a menos que toda fenomenologia que recuse o mundo reduzido - independentemente se do Dasein, da percepção ou da consciência situada - seja de antemão ingênua, e ingênuo signifique desrespeitar o modelo e projeto husserlianos. Ainda assim, porque a ontologia de Sartre nasce do mundo e com o mundo, a "determinação do para-si como falta responde bem às exigências do a-priori correlacional", mesmo que "tudo se passe como se o para-si, que é isso que advém ao em-si, retomasse por sua própria conta esse esforço de fundação, e encaminhasse [tendait vers] a realização da causa de si ou da autofundação à qual o em-si aspira" (Barbaras, 2005, p. 129-130). No horizonte sartriano, vale dizer, esse tipo de questionamento não se aplica à ontologia: é metafísico. Ou seja,

[...] algo vem do ser: aquilo que, à falta de expressão melhor, denominaremos abolições e aparições. Essas aparições e abolições devem ser objeto de elucidação puramente metafísica e não ontológica, pois não se poderia conceber sua necessidade a partir das estruturas de ser do Para-si nem daquelas do Em-si: sua existência é a de um fato contingente e metafísico (Sartre, 2011, p. 272). 
Além disso, essa distinção coloca em xeque todas as interpretações de Sartre que o consideram o último metafísico em razão de buscar o fundamento. Fica anotado que a distinção proposta por Sartre dos domínios da investigação filosófica justifica previamente sua ontologia. O mesmo parece aplicável ao questionamento de Barbaras, que exige uma decisão unívoca: a dicção absoluta não figura no ambiente ontológico sartriano, visto que, para ele, ela não pode jamais ser cumprida; o homem existe, e só. Ainda assim, a crítica barbarrariana é precisa:

[...] ou bem mantém-se o abismo ontológico entre o em-si e para-si, mas então é necessário renunciar à correlação; ou bem parte-se efetivamente da correlação, mas então é necessário concluir que a totalização não é somente ideal (pois impossível), que existe então um horizonte de reconciliação e que a relação do sujeito e do objeto deve escapar à alternativa da unidade e da dualidade (Barbaras, 2005, p. 132).

Assim, a decisão final cabe aos filósofos; fenomenologicamente ambos têm razão, mas qual é efetivamente o papel da razão no meio fenomenológico? Sartre insiste que o trabalho da ontologia foi feito; e isso que se lhe opõem, por mais razões que tenham Merleau-Ponty, Barbaras ou tantos outros, acaba adentrando o campo da metafísica. Mas, nesse ponto, também Sartre é direto:

A ontologia, portanto, limitar-se-á a declarar que tudo se passa como se o Em-si, em um projeto de fundamentar a si mesmo, se concedesse a modificação do Para-si. Compete à metafísica formar as hipóteses que irão permitir conceber esse processo como o acontecimento absoluto que vem coroar a aventura individual que é a existência do ser (Sartre, 2011, p. 757).

Conforme já dito, se toda metafísica exige sua teoria do conhecimento, a ontologia de Sartre é fenomenológica; mas, do mesmo modo, toda teoria do conhecimento também tem sua metafísica. Cabe então perguntar sobre a metafísica que subjaz à verdadeira fenomenologia, que a faz negar o que é (mundo) em função daquilo que deveria ser.

\section{Referências}

Barbaras, R. (2005). "Désir et manque dans L'Être et le Néant: le désir manqué", in Barbaras, R. (Org.). Sartre, désir et liberté. Paris: PUF, p. 113-140.

Da Silva, L. (2018). Ética e liberdade em Sartre - da negação da infância ao homem infantilizado. Curitiba: Appris.

Heidegger, M. (1973). Sobre a essência do fundamento. Trad. Ernildo Stein. São Paulo: Abril Cultural.
Heidegger, M. (2005). Ser e tempo. Trad. Márcia S. C Schuback. 15. ed. Petrópolis, RJ: Vozes.

Husserl, E. (2013). Meditações cartesianas e Conferências de Paris. Trad. Pedro Manuel Santos Alves. Rio de Janeiro: Forense Universitária.

Husserl, E. (1990). A ideia da fenomenologia. Trad. Artur Mourão. Lisboa: Edições 70.

Husserl, E. (1994). Notes sur Heidegger. Trad. Didier Franck. Paris: Minuit.

Maurano, D. (2006). Para que serve a psicanálise? 2. ed. Rio de Janeiro: Jorge Zahar.

Merleau-Ponty, M. (2005). O visível e o invisível. 4. ed. Trad. José A. Giannotti e Armando M. d'Oliveira. São Paulo: Perspectiva.

Merleau-Ponty, M. (2006). Fenomenologia da percepção. Trad. Carlos A. R. de Moura. 3. ed. São Paulo: Martins Fontes.

Parmênides (s/d). Poema. Fragmento 3. Trad. Fernando Santoro.

Safatle, V. (2009). Lacan. 2. ed. São Paulo: Publifolha.

Sartre, J-P. (1938). Esquisse d' une théorie des émotions. Paris: Hermann.

Sartre, J-P. (1952). Saint Genet, comédien et martyr. Paris: Gallimard.

Sartre, J-P. (1963). Baudelaire: note de Michel Leiris. Paris: Gallimard.

Sartre, J-P. (1971). L’idiot de la famille. Paris: Gallimard.

Sartre, J-P. (1973). A imaginação. Trad. Luiz R. S. Fortes. São Paulo: Abril Cultural.

Sartre, J-P.(1978). O existencialismo é um humanismo. Trad. Vergílio Ferreira. São Paulo: Abril Cultural.

Sartre, J-P. (1986). Mallarmé: la lucidité et sa face d'ombre. Paris: Gallimard.

Sartre, J-P. (1994). A transcendência do ego; Consciência de si e conhecimento de si. Trad. e introd. Pedro Manuel dos Santos Alves. Lisboa: Colibri.

Sartre, J-P. (1996). O imaginário. Trad. Duda Machado. São Paulo: Ática.

Sartre, J-P. (2002). Crítica da razão dialética. Trad. Guilherme J. de F. Teixeira. Rio de Janeiro: DP\&A.

Sartre, J-P. (2005). Situações I. Trad. Cristina Prado. São Paulo: Cosac Naify.

Sartre, J-P. (2011). O ser e o nada. 20. ed. Trad. Paulo Perdigão. Petrópolis, RJ: Vozes. 
Luciano Donizetti da Silva é Doutor em Filosofia Contemporânea pela Universidade Federal de São Carlos, Professor de Filosofia do Instituto de Ciências Humanas (Departamento de Filosofia) e do Programa de Pós-Graduação em Filosofia da Universidade Federal de Juiz de Fora (UFJF). Realizou estágio pós-doutoral pela Université Jean Moulin, Lyon III, França, em 2016. É autor de dois livros: Ética e liberdade em Sartre: da negação da infância ao homem infantilizado (Curitiba: CAPES Appris, 2018) e A filosofia de Sartre entre a liberdade e a história (São Carlos, SP: FAPESP-Claraluz, 2010). Além disso, publicou inúmeros artigos em revistas especializadas bem como capítulos de livros. E-mail:donizetti.silva@hotmail.com

Recebido em 29.11.2017

Aceito em 13.05.2018 